\title{
"A QUESTION OF SELF-INTEREST": A BRIEF HISTORY OF 50 YEARS OF INTERNATIONAL STUDENT POLICY IN CANADA
}

\author{
DALE M. MCCARTNEY \\ UNIVERSITY OF THE FRASER VALLEY
}

\section{Abstract}

This article offers a periodization of the history of international student policy in Canada since 1970. It draws on archival sources at seven public post-secondary institutions in British Columbia and Ontario, as well as governmental discussion in both provinces and at the Federal level, and scholarly writing about international students within the Canadian Journal of Higher Education to construct this history. Four key periods are identified: the emergence of differential fee policies in the 1970s; an era of institutional recruitment efforts in the 1980s and 1990s; a period of active government recruitment in the 2000s; and an era of bifurcating priorities as governments expanded their recruitment efforts but scholars began to question the international student project in Canada. The article shows changes in international student policy over the past half-century, but also reveals continuities, most notably a sustained emphasis on serving Canada's perceived national interests.

Keywords: international students, internationalization, differential fees, history of higher education, Canadian Journal of Higher Education

\section{Résumé}

Cet article propose une périodisation de l'histoire des politiques relatives aux étudiants étrangers au Canada depuis 1970. II s'appuie pour ce faire sur les archives de sept établissements d'enseignement postsecondaire publics de la Colombie-Britannique et de l'Ontario, sur les discussions gouvernementales dans les deux provinces et au fédéral, ainsi que sur les articles savants de la Revue canadienne d'enseignement supérieur portant sur les étudiants étrangers. Quatre périodes clés ressortent : l'émergence des politiques de frais différentiels dans les années 1970; une phase d'efforts de recrutement au sein des établissements dans les années 1980 et 1990; une phase de recrutement actif de la part du gouvernement dans les années 2000; et une bifurcation des priorités lorsque les gouvernements ont intensifié leurs efforts de recrutement et que les chercheurs se sont mis à remettre en question le projet relatif aux étudiants étrangers au Canada. Cet article pointe des changements dans les politiques relatives aux étudiants étrangers au cours du dernier demi-siècle, mais il révèle aussi des éléments de continuité, notamment dans l'accent mis sur le fait de servir ce qui est perçu comme les intérêts nationaux du Canada.

Mots-clés : étudiants étrangers, internationalisation, frais différentiels, histoire de l'enseignement supérieur, Revue canadienne d'enseignement supérieur

\section{Introduction}

This article offers a new periodization of the last half-century of international student policy. It does this by tracing-both at the institutional and governmental level, and in the academic literature, especially the $\mathrm{Ca}$ nadian Journal of Higher Education (CJHE)-policy discussion regarding international undergraduate students.
It chronicles and offers some explanation for the seismic changes in the way international students are thought about and treated in Canada. The article begins when the Canadian Society for the Study of Higher Education (CSSHE) did, in an era when international students were seen as targets for charity, grateful sojourners who Canada should fund so that they returned to their country of citizenship as agents for Canadian Cold War foreign 
policy. It concludes in an era when international students are seen as wealthy cosmopolitans, and most Canadian post-secondary institutions depend on the billions of dollars international students bring to Canada every year.

This article is not a story of progress, nor of decline; it is a history that shows the deep roots and complex motivations of contemporary international student policy, and the ways in which it is enmeshed in nation-building efforts in Canada. For all the change that has occurred, though, this history shows the ongoing power of a Canada-first focus within policy that belies, or betrays, claims to educational internationalism.

\section{Methods}

This article attempts to offer a synoptic overview of 50 years of complex history as succinctly as possible. It draws on a larger research project examining the history of internationalization and international student policy, which relied on materials gathered during research visits to archives of seven post-secondary institutions in British Columbia (B.C.) and Ontario, as well as discussion and debate in the provincial legislatures and the federal Parliament that was collected from Hansard online. Given the impossibility of a true national survey of institutions, these seven were chosen to give a broad cross-section of types of institutions in English Canada. The article examines two large research universities: the University of Toronto (UofT) and the University of British Columbia (UBC); two comprehensive universities: Carleton University and Simon Fraser University (SFU); two smaller, primarily undergraduate universities: Wilfrid Laurier University (WLU) and Kwantlen Polytechnic University (KPU); and one of Canada's largest colleges, Seneca College. These two provinces were chosen because they receive the largest number of international students in Canada today (Canadian Bureau for International Education, 2018). While these selections do not represent every type of post-secondary institution or region of the country, useful lessons can be drawn by comparing their histories of international student policy.

To this material the article adds a close examination of the history of scholarship about international students and internationalization within CJHE. This is not a literature review, but instead treats this scholarship as historic artifacts of the time in which it was produced (inspired by work such as Chakrabarty, 2000; Gottesman, 2016;
Smith, 1998). This sort of intellectual history is less concerned with the specific contents of this academic material, and more focused on how that scholarship reflects and shapes broader public debates about international student policy.

Drawing on this rich collection of materials, this article employs an historical form of critical policy analysis (Brewer, 2014; Gale, 2001). An historical approach helps to trace and explain both continuity and change in a particular set of policies (Gale, 2001). To explain these patterns over time, the historical approach relies upon periodization. Periods are "a means of organizing change into coherent, if always partially heuristic, units," in the process "render[ing] it intelligible" (Stearns, 1984, p. 92). In this case, by situating the development of international student policy in the larger historical trajectory of institutions, governments, and the contents of CJHE, this article is able to capture the decisive shifts in this history, periodizing the development of the current policy landscape and thereby explaining the formative political processes that led to it.

By viewing the development of the policy in historical trajectory, the underlying debates shaping that policy come into view. To highlight the complexity of the policy-making process, I have approached the source material here as examples of what American educational historians Tyack and Cuban (1995) call policy talk-debate about possible policy directions that does not necessarily translate to finished policy, but represents the landscape of policy options being explored in a given historical moment. This approach helps to capture the debates that went into the formation of the policy, without oversimplifying the correspondence between discussion of policy and its enactment.

\section{Theoretical Framework}

This article is shaped by Harney's (1988) assertion that discussions of (im)migration in the Canadian context are always existentially important to the idea of the Canadian nation, and that in the eyes of Canadian policy makers, "the migration phenomenon exists to serve" Canada, not migrants themselves (p. 53). Thus, this article examines discussions of international students as part of the process of (re)defining the boundaries of the Canadian nation. Debates about international students are a site of struggle over the benefits of Canadian cit- 
izenship, not only as a marker of identity but as an expression of social power and access to resources (Walia, 2013). Bannerji (2000) reminds us that even citizenship does not necessarily mean membership in the nation of Canada; she comments that people of colour in Canada are confronted by a host of policies and labels that "originate in the ideology of the nation" and enforce "the paradox of both belonging and non-belonging simultaneously" (p. 65). In this article, I trace the (re)construction of taken-for-granted assumptions about Canadian nationhood and belonging in policy talk about of international students since 1970 , in an effort to identify how and why a fairly small set of ideas about international students and their value to the Canadian nation have become hegemonic in contemporary policy.

\section{Literature Review}

There has been important work done already to historicize international student policy in Canada, starting even before the period examined in this article (Cameron, 2006; Levi, 2009; McCartney, 2016; Poitras, 2017, 2019). A small number of studies have examined Canada's engagement with international education in the 1970-2000 period as well. Allison $(2007,2016)$ and Trilokekar $(2007$, 2010) are the leading figures here. Both Allison and Trilokekar analyze the role of federal-level organizations in guiding international education, with Allison focused on the Council of Ministers of Education of Canada, and Trilokekar emphasizing the role of the department of Foreign Affairs. Their work also differs from this study in that it explores international education much more broadly than this article, with limited attention to the specifics of international student policy. However, despite these differences, both scholars periodize the history of international education in a similar pattern to that advanced here. Both scholars identify the early 1970 s as a period in which Canada's agenda for international education changed, at least in part due to the global economic crisis of that era, and both see the mid- to late-1980s as another moment of transition (Allison, 2016; Trilokekar, 2007). Both scholars end their studies before the year 2000 , making it impossible to know if a shared periodization would continue. Regardless, although both scholars employ different theoretical approaches (from each other and from this study), and ask different questions of the material they are examining, these parallels suggest the accuracy of our shared periodization.
Most of the scholarship examining the history of international student policy in Canada has focused on the period after 2000 , an era that is commonly associated with internationalization (Knight, 2015). A central focus in this work has been the issue of a federal-level internationalization strategy, which was not created until 2014 (Government of Canada, 2014), and the effect its absence and then creation has had on Canadian international student policy (e.g., Anderson, 2015; Bégin-Caouette, 2018; Desai-Trilokekar \& Jones, 2015; Garson, 2016; Johnstone \& Lee, 2014, 2017; Knight-Grofe \& Deacon, 2016; Sá \& Sabzalieva, 2018; Tamtik, 2017; Tamtik et al., 2020; Trilokekar \& El Masri, 2016a, 2016b; Trilokekar \& Kizilbash, 2013; Viczko \& Tascón, 2016). The effect of this focus has been to situate the creation of the national strategy as the central event in the history of international student policy. For example, Sá and Sabzalieva (2018) frame the period before the creation of a national policy as Canada "playing catch-up" in comparison to other Anglo-American countries that receive large numbers of international students (p. 241), and Trilokekar and Jones (2020) described that time as "characterized by multiple and uncoordinated processes" as a result of the failure of federal government to set a national agenda (p. 30). But the new national policy is heralded as a dramatic change (Trilokekar \& El Masri, 2016a) which signalled that Canada had entered a new era, with an increased emphasis on international student recruitment (Knight-Grofe \& Deacon, 2016).

This periodization is not inaccurate, but it is incomplete. This article argues that there was considerable continuity in international student policy between these two periods, threads that originated before the turn of the century. Moreover, this framing makes it appear that there was no national policy consensus in the period before the creation of Canada's international education strategy. While there was not an official international education policy at the federal level, as this article shows, there was a shared perspective that shaped policy in both British Columbia and Ontario, suggesting that there was a framework within which all provinces and institutions were working. My assertion is that the periodization chronicled here demonstrates that the federal government had greater influence than is usually recognized, especially through immigration policy. Moreover, important policy shifts-such as the emergence of differential fees-occurred at roughly the same time across the nation because institutions and provincial governments 
shared a set of priorities that reflected a Canada-first perspective that has remained in force throughout the history of international students in Canada.

\section{Findings}

\section{Monetizing Migrants: The Emergence of Differential Fees (1970-1985)}

When the Canadian Society for the Study of Higher Education (CSSHE) was formed in 1970, there were more than 15,000 international students attending Canadian post-secondary institutions (about $5 \%$ of all students); by 1974 , there were more than 20,000 (comprising $6.3 \%$ of the total population) (University of Toronto Students' Administrative Council, 1975; Wisenthal, 1999). Yet despite their substantial numbers, there was very little policy discussion of them. At an institutional level, groups like Friendly Relations with Overseas Students (FROS) had been working since 1949 to develop student services specifically meant to support international students (Poitras, 2019), and there was some discussion of international students in Parliament and the Department of External Affairs (McCartney, 2016; Trilokekar, 2007,2010 ), but these discussions were fairly marginal within the institutional contexts in which they occurred. Even this limited discussion exceeded the scholarly attention paid to international students, though. Indeed, there was no discussion of international students in the CJHE until the late 1980s (Holdaway et al., 1988; Zelmer \& Johnson, 1988). Overall, attitudes toward international students might best be described as a somewhat patronizing neglect, with little concern about them or their place in the Canadian post-secondary system at the start of the 1970s (McCartney, 2016).

Despite the quiet beginning, the first period under discussion here, starting in the 1970 s and early 1980 s, featured the emergence of a national consensus around international students, and the beginnings of most of the key elements of contemporary international student policy in Canada. Three key developments stand out from this period, and serve as the foundation for the internationalization era in Canadian policy regarding international students: the classification of international students as migrants, and therefore undeserving of taxpayer support; the adoption of differential tuition fees; and the standardization of the notion of international students as relatively wealthy foreigners, in contrast to past views of them as targets for foreign aid. Although this era featured the development of policy regarding international students, it largely lacked scholarly literature examining that policy. There was one organization, though, that served both as a key venue for research about international students and the clearing house for policy production regarding them-the Canadian Bureau for International Education (CBIE). The work of the CBIE naturalized the new policy directions emerging in the late 1970s, and provided the basis for views of international students as outsiders that would last for decades afterwards.

The first important change to international student status in the 1970s happened at the federal government level. Starting in 1967, international students had been able to apply for immigrant status during their studies, and their education had meant they would be strong candidates (Canadian Service for Overseas Students and Trainees, 1967). However, in the late 1960s and early 1970s there was a backlash against international students, catalyzed by the events of the Sir George Williams University Affair. Members of Parliaments' attitudes toward international students became increasingly hostile, and when the federal government reformed immigration policy in 1976, it moved to close students' immigration pathway (McCartney, 2016). The Immigration Act of 1976 formally designated international students as visitors, meaning they came to Canada "for a temporary purpose," were barred from working in Canada, could not change institutions or program of study after arriving, and were prohibited from applying to be an immigrant while in Canada (Immigration Act, 1976, p. 4). In effect, they were made into a category of migrant, permanent outsiders to the Canadian nation. This was a substantial reform, and laid the foundation for one of the most important and lasting changes to international student policy: differential tuition fees.

Although the Immigration Act was a federal policy, and differential fees were provincial, one enabled the other. This is clear from the language offered by the Ontario Minister of Colleges and Universities, Harry Parrott, when he introduced the policy in 1976. He made it clear that the new fees, which were nearly triple the rate charged to domestic students, would only apply to what he called (echoing the terminology of Canada's migrant worker policy) "non-immigrant foreign students" (Parrott, 
1976, p. 2; see also Sharma, 2006). This was a matter of citizenship, as new Canadians, refugees, and students from other provinces would be spared the increase. Although Ontario institutions were initially resistant to the new policy, by the fall of 1977 all of them except McMaster and Trent had implemented the new fees (Roberts \& Adam-Moodley, 1977). Soon after Ontario implemented differential fees, Alberta (1977), Quebec (1977), New Brunswick (1979), Nova Scotia (1979), and Prince Edward Island (1979) all followed suit (Commission on Foreign Student Policy in Canada, 1981).

Even in provinces that did not enact an official differential fees policy, however, institutions were induced to adopt them through other means. British Columbia is illustrative here. Initially, B.C. institutions were opposed to differential fees (Campbell, 1980b). However, when the Social Credit government of British Columbia drastically cut post-secondary budgets in 1982, institutions were forced to reconsider (Fisher et al., 2014). Simon Fraser University introduced differential fees in immediate response to the first cuts, and UBC followed suit in 1984 (Jordan, 1982; McBlane, 1984). As SFU President William Saywell explained in 1983, international students had to pay differential fees because "the university needs funds, because there is not enough" in the provincial budget (as quoted in Leong, 1983, p. 5).

Although institutions across Canada grudgingly enacted the differential fees in the late 1970s or early 1980s, it did not mean the policy was uncontroversial. Campus student groups described the fees as "racist" (Campbell, 1980a, p. 1; Canadian University Press, 1976, p. 6; "Fees Up for Foreign Students," 1976, p. 4) and "discriminatory" (Canadian University Press, 1977, p. 1; Shaw, 1983, p. 1). International student service professionals also resisted the fees, publicly criticizing the idea even before the policy was official ("Foreign students in Canada," 1975), and writing letters to provincial and federal ministers trying to convince them to change the policies (McBlane, 1981; University of British Columbia International House Board of Directors, 1983). Even Members of Parliament (MPs) expressed dismay at the idea of differential fees, with one opposition MP pointing out that Prime Minister Pierre Trudeau had not paid a differential rate when he attended the Sorbonne or Harvard (Fairweather, 1976; see also Lambert, 1972).

Yet despite these critiques, differential fees became accepted practice very quickly, and serious critiques of them largely disappeared from policy discussion in less than a decade. A key part of normalizing the new policy was the work of the Canadian Bureau for International Education (CBIE). The CBIE received a grant in 1977 to do a national study of international students and policy related to them, and published the results of the survey (Neice \& Braun, 1977), a set of research papers (Hettich, 1977; Roberts \& Adam-Moodley, 1977; Sabourin \& Moore, 1977; von Zur-Muehlen, 1977), and a slim volume of policy recommendations entitled $A$ Question of Self-Interest (Canadian Bureau for International Education, 1977). Collectively, these documents were an attempt to "provoke debate and shape opinions" about the underexamined issue of international students in Canada (p. 1). They were the first serious scholarly examinations of international students in Canada, and so represent an important intervention worthy of examination. Though space precludes a deep discussion, it is clear that the CBIE's work promoted a shift in thinking about international students that helped justify the creation of differential fee policies.

This is perhaps most obvious in the way international students are described in the documents. In the 1950s and 1960s international students had been seen, especially by CBIE predecessor FROS, as "lost in a strange, cold, and sometimes hostile world" in need of support and care, which should be offered by universities and Canadians more broadly (Poitras, 2019, p. 32). But the CBIE proposed a very different view of international students in this collection. In contrast to past policy talk, which had emphasized the impoverished nature of their home countries (e.g., Sanguinetti, 1960), the CBIE publications focused on the relative socio-economic advantage of international students over their compatriots. They came from "status privileged sectors of their own societies"; the "bulk" of them were "the children of either entrepreneurs or businessmen"; and the majority had family members who had also studied overseas (Neice \& Braun, 1977, p. 37). According to these CBIE reports, international students were not the needy aid-targets many had imagined them to be; they were a cosmopolitan economic elite, making rational choices from a host of possible educational options. This view emphasized international students' "non-belonging" (Bannerji, 2000, p. 65) and suggested new ways they could serve Canada's interests.

Given this information, the CBIE had a new set of 
priorities to offer post-secondary institutions. International students were no longer just an extension of Canada's foreign policy goals; they could benefit Canada in other ways. The CBIE explained "we believe that Canada's self-interest can be served" by international students, if one or more of three conditions were satisfied: if the presence of the students improved "the quality of the educational experiences offered by the institution"; if receiving international students serve Canada's "long or short-range economic or political interests"; or if there was "an immediate financial return" from international students (Canadian Bureau for International Education, 1977, p. 10). Although differential fees were still being debated across the post-secondary sector, by 1977 the CBIE had laid out the rationale that would sustain international education, and especially student mobility, well into the 21st century. The authors of $A$ Question of Self-Interest could not have known the enormous geopolitical changes that were on the horizon in the 1980s and 1990s, but their framework provided the groundwork for those changes.

\section{Funding Cuts and International Student Recruitment: The Dawn of the Internationalization Era (1985-2001)}

This second period, which stretches from the mid-1980s to the passage of the Immigration and Refugee Protection Act of 2001, is traditionally when internationalization is said to have first become an institutional priority. At least as pertains to international student policy though, this was actually a period of calcification of already existing trends, particularly differential fees. There is some change, particularly in the tone of discussion of international students. Influential scholars such as Jane Knight positioned international student mobility as one element of the process of internationalization, and argued for its academic importance. This shift is often linked to the end of the Cold War, and it is reasonable to argue that this was a factor (Wollitzer, 1991). However, close examination of internal institutional debate shows that while the public discussion emphasized the educational value of internationalization, institutions themselves were much more focused on the fiscal importance of increasing international student enrolment.

Differential fee policies were the first step to incentivizing post-secondary institutions to recruit interna- tional students, and the 1980 s and 1990s showed that the incentives worked. Institutions in British Columbia had been focused on the revenue potential of differential fees from their inception, as they introduced them to replace budget shortfalls (Jordan, 1982). But it was the cutbacks of the 1990s (Fisher et al., 2014) that drove institutions to develop active recruitment strategies. A good example in British Columbia is UBC's international student initiative (ISI). The ISI is an ongoing institutional effort first launched in 1996. Its initial task was to rapidly increase UBC's number of international undergraduate students from less than $3 \%$ of the undergraduate student body to between $13.5 \%$ and $15 \%$ (Birch, 1996b; International Student Initiative, 2002). The catalyst for UBC to begin actively recruiting international students was the B.C. government deregulating international tuition rates, which allowed UBC to move to a "market-based tuition for international students" starting in the 1997-98 academic year (Birch, 1996a, p. 4). There had been calls for UBC to increase its recruitment of international students in the past (e.g., McBlane, 1986), but it was economic incentives that led to the establishment of recruitment programs like the ISI.

In Ontario, differential fees did not immediately spark a recruitment drive, because the revenue initially went to the province to offset the cost of post-secondary education. However, in 1984 Ontario's government changed this policy, distributing the surplus funds throughout the province's institutions instead (Welch et al., 1984). The government also partially deregulated international student tuition, allowing institutions to set it themselves (International House at the University of British Columbia, 1983). The result was a change in institutional priorities. For example, at UofT an internal 1975 report found that most faculties and schools within the university limited admission of international students, sometimes with explicit percentage quotas ("Some University of Toronto Policies Concerning Student Visa Applicants," 1975). But a 1984 task force, writing after the policy change redistributing the additional fees to Ontario universities, suggested that UofT should become "actively engaged, in the context of available resources, in recruiting outstanding foreign students" (Israel \& Lang, 1985, p. 13), at least in part because the $\$ 6.6$ million that UofT would gain from international students in 1984-85 was money the university could not "afford to lose" (p. 27). After all, the task force pointed out, the fees benefitted "all students, including foreign students" (p. 27) because they 
funded the university's operations. Similar patterns repeated at smaller institutions. At Wilfrid Laurier University (WLU), for example, an international education strategy was designed in the early 1990 s that included a resolution to create an office responsible for developing "a policy for recruitment of international students" and "a strategic plan to 'market' Laurier in other countries" (The Ad Hoc International Education Strategy Committee, 1993, p. 13). Seneca College, too, developed a strategy to recruit more international students in the 1990s, which led to the creation of an English Language Institute, a predecessor to the pathway programs that Canadian universities have developed in the 2000s (Bartsiokas et al., 2017). The arrival of differential fees drove significant changes in the Canadian post-secondary sector, and reinforced the place of international students as outsiders who could serve Canadian interests by helping to fund its public post-secondary system.

Not coincidentally, this era saw the beginnings of serious scholarly interest in international students, likely in part because these recruiting efforts were making them a bigger part of the everyday life of Canadian academics. In 1988, CJHE published two important papers examining international students at the University of Alberta, the first articles in its pages to examine international students in detail (Holdaway et al., 1988; Zelmer \& Johnson, 1988). International students were also discussed in the context of entrepreneurialism and privatization in the Canadian post-secondary system (Michael \& Holdaway, 1992; Rae, 1996). These pieces were part of a new scholarly focus on what soon came to be called internationalization.

The term "internationalization" was adopted to explain the changes wrought on post-secondary education by the arrival of globalization (Beck, 2012). Although, as we have seen, a significant proportion of what is now called internationalization was already underway on campuses well before the 1990s, scholars generally treated the large-scale movement of students as one component of an institutional and sectoral shift to more global priorities and perspectives that began with the end of the Cold War (Kerr, 1991; Wollitzer, 1991). In Canada, Jane Knight provided an authoritative definition of internationalization that set the boundaries of scholarly discussion of internationalization for decades. She focused on the effect internationalization had on teaching, research, and service, but offered less discussion of its impact on institutional finances (e.g., Knight, 1994, 1997, 2004, 2015). Knight's work situated internationalization as an inevitable result of globalization (Stein, 2017b), and emphasized its academic benefits (Beck, 2008). This meant that while fiscal pressures were the driving force for institutional recruitment efforts, public discussion focused on the intellectual value of increasingly globally engaged campuses.

\section{Post-Secondary Institutions Open for Business: International Education as a Vital Canadian Export Industry (2001- 2014)}

If the 1980s and 1990s featured the emergence of institutional campaigns to recruit international students, the early 2000s were characterized by a broadening and deepening of that project, as the federal government enacted supportive policies and developed strategic plans to expand international student recruitment, and institutions explored new ways to increase enrolment by differential fee-paying students, including developing partnerships with for-profit multinational education corporations. Recruiting international students was increasingly a part of advancing Canada's national interests. Meanwhile, the CJHE reflected the excitement for the opportunities presented by internationalization, as a massive expansion of scholarship on the topic generally focused on how to internationalize effectively. Until the 2010s, administrators, academics, and policy makers alike shared excitement about the potential of international student mobility, resulting in an era characterized by institutional and policy change meant to garner ever-growing numbers of international students.

Although budget cuts to post-secondary institutions had been driving differential fee policies and international student recruitment efforts for 15 years by the time the 21st century began, neither provincial nor federal governments had directly supported those recruitment efforts. However, in 2001 the federal government, with the support of Canadian institutions, revised Canadian immigration policy to make studying in Canada the first step on a path to citizenship (Association of Universities and Colleges of Canada, 2001; Brunner, 2017). The justification for the change was economic, in the immediate term because it would aid institutions to recruit interna- 
tional students (Association of Universities and Colleges of Canada, 2001), but also in the longer term because the federal government increasingly saw international students as ideal immigrants and a vital part of Canada's economic future.

The possibility of permanent residency was a boon to recruiting efforts, and it soon featured prominently in advertising material aimed at international students, including in the government's own advertisements. The federal government launched a national brand for its international education efforts in 2008, to support institutional efforts to increase international student numbers (Trilokekar \& Kizilbash, 2013). Called "EduCanada," it used an online presence and advertisements to set Canada "apart from host nation competitors through an emphasis on post-graduation immigration possibilities" (Stein, 2017a, p. 10). This advertising was effective, with one CBIE study suggesting more than half of the international students who come to Canada intended to immigrate, and more than two-thirds were motivated to come to Canada because of the opportunity to work in Canada after graduation (Stein, 2017a).

The quest to secure a greater number of international students, especially the fees they paid, continued to shape institutions as well. By 2014 more than $80 \%$ of Canadian institutions were participating in overseas recruitment fairs, and more than half employed student recruiters or agents to increase the number of international undergraduates on their campuses (Association of Universities and Colleges of Canada, 2014, p. 23). But a more remarkable change was the creation of pathway programs and even pathway colleges. These catered to international students who lacked the academic or linguistic credentials for direct entry to a Canadian institution (Rahilly \& Hudson, 2018). While pathway programs had existed in other countries since the 1980s, SFU opened the first pathway in Canada in 2006 (Agosti \& Bernat, 2018; Rahilly \& Hudson, 2018). As an institutional form, they spread rapidly across the country; by $201872 \%$ of the members of Universities Canada had at least one pathway program or affiliation, including all of the universities examined in this study (McCartney \& Metcalfe, 2018). A significant number (32\%) of these pathways were partnerships with private, for-profit educational corporations (McCartney \& Metcalfe, 2018). However, even the pathways controlled directly by the parent institution follow a similar pattern to the private partnerships at other institutions. International students who are not able to enter the parent institution directly are charged differential fees while completing upgrading programs, sometimes with a mixture of courses that would count for credit at the parent institution should the students successfully matriculate. Most programs (88\%) offer students conditional entry to the parent institution, as long as they complete a set of predetermined academic goals (McCartney \& Metcalfe, 2018).

These pathways, especially the partnerships with private, for-profit providers, were often controversial when they were introduced. At SFU the creation of a partnership with Australian multinational Navitas was hotly contested, but despite internal resistance the pathway program opened in 2006 (e.g., Harder \& SFU Student Society Board of Directors, 2006; Senyshyn \& SFU Faculty Association Executive, 2006; Simon Fraser University Teaching Support Staff Union Executive, 2006). At Carleton a similar partnership was mooted, but ultimately failed as a result of the pushback from campus unions and a few especially outspoken critics on the Senate (e.g., Falvo, 2010a; Fanelli \& Meades, 2011; "Unions oppose Navitas," 2010), although Carleton would eventually form a partnership with a Canadian for-profit provider called CultureWorks ("Editorial: CultureWorks Raises Questions," 2012). At both institutions the resistance focused on the fact that Navitas was a private company; the idea of creating a pathway program that would increase revenue for the institution was not controversial, the debate was simply who would run it (e.g., Falvo, 2010b).

The question of international students (and internationalization generally) was not just changing Canadian post-secondary institutions; it was changing the scholarship discussing Canadian higher education as well. The period between 2001 and 2014 featured an explosion of interest in international students in the pages of the CJHE. Articles discussing the recruitment and admission of international students and their impact on institutions were suddenly common (e.g., Cudmore, 2005; Dennison, 2006; Dennison \& Schuetze, 2004; Lang \& Lang, 2002; Levin, 2002, 2003; Walker, 2008), as were discussions of the challenges international students faced on campuses, including racism (e.g., Duclos, 2011; Grayson, 2007; Guo \& Jamal, 2007; Kenyon et al., 2012; Mueller, 2009; Samuel \& Burney, 2003). There was also some discussion of internationalizing curriculum (e.g., Freeman \& Knight, 2007; Prowse \& Goddard, 2010; Schuerholz-Lehr et al., 2007). Overall, this expanded 
scholarly concern makes sense given the governmental and institutional attention paid to international students in this era. In many ways this work reflected a sincere grappling with the challenges created by an increasingly international student body, but also an engagement with the promise of student mobility. While some pieces did discuss the fiscal impact of international students (e.g., Boggs, 2009; Dennison \& Schuetze, 2004), in general the CJHE's authors focused on actually implementing internationalization and international education effectively. This is not to say this expanded scholarship is not critical, but it generally revolves around an emphasis on trying to do the work of internationalization well. As with institutions and governments, this was an era in which the expansion of international education was seen mostly as a worthy technical challenge, rather than an ethical or educational dilemma.

\section{A Critical Turn: The End of the International Student Consensus? (2014-2020)}

However, by the 2010s attitudes were beginning to diverge. The economic impact of international students was made clear in 2012, when a national report declared international education a more valuable export than unwrought aluminum or helicopters and airplanes (Roslyn Kunin \& Associates, 2012). Governments responded with more encouragement to institutions to recruit students. British Columbia created a provincial international education strategy that called for the province to increase its international student numbers by $50 \%$ over four years (British Columbia Ministry of Advanced Education, 2012). Two years later, the federal government released its international education strategy, a profoundly economic document that made almost no reference to curricula (except as something to be sold for profit to institutions in other countries), but did provide detailed targets for increasing the recruitment of international students, both in absolute terms and by diversifying the source countries to better serve Canada's foreign affairs agenda (Government of Canada, 2014). This first national strategy document signalled the incorporation of post-secondary education into Canada's economic policy regime as a major export, and in that sense is a milestone in the commodification of education in Canada. However, in contrast to much of the literature, which treats it as the beginning of federal-level international student policy in Canada, the new strategy document formalized a trajectory that we have already seen had its roots in the 1970s, and was defined by a sustained focus on the notion of a national interest in international student policy.

It did mark the end of whatever limited consensus had been present between scholars, administrators, and government officials in the discussion of international student recruitment. The CJHE shows a marked change around 2014, with a more critical turn emerging in discussions of internationalization. There were still articles examining how to better support international students (e.g., Cui et al., 2017; Giamos et al., 2017; Green et al., 2018; Malette \& Ismailzai, 2020; Montsion, 2018; Robertson et al., 2015), but even these took an increasingly critical turn. For example, a number of articles examined the increased vulnerability of international students to personal financial challenges, including food insecurity (Bottorff et al., 2020; Calder et al., 2016; Frank, 2018; Maynard et al., 2018). While these kinds of articles recognized international students as a vital part of Canadian campuses, they were less sanguine than the previous generation about the challenges that international students faced.

Even more strikingly, CJHE published a number of articles that challenged the underlying assumptions of internationalization, and raised questions of the justice of internationalization policy as it was being enacted (Anderson, 2015; Buckner et al., 2020; Garson, 2016; Larsen, 2015; Masri, 2020; McCartney, 2020; Stein et al., 2019; Trilokekar \& Kizilbash, 2013; Viczko \& Tascón, 2016). Although these articles have very different theoretical and axiological orientations, they nonetheless represent the emergence of a critical position in contrast, and perhaps even in conflict, with the underlying assumptions that have shaped state-level discussion of international students in Canada since the late 1970s.

Yet government efforts to encourage the recruitment of international students have not diminished. Canada's 2014 strategy called for Canadian institutions to double the number of international students in Canada by 2022 (to a total of more than 450,000) (Government of Canada, 2014). Canada surpassed that goal in 2017 (Canadian Bureau for International Education, 2018). Canada's new international education strategy encourages institutions to recruit students from a broader array of coun- 
tries, because "as a trading nation, Canada must continually expand and diversify not only its customer base, but also its roster of potential exporters" (Government of Canada, 2019, p. 4). This is a continuation of a trajectory that started in the 1970s, reworked to reflect the specific demands of the Canadian state in 2019. Yet there is an enormous gap between these priorities and the tenor of academic scholarship about internationalization in the last five years. This suggests that 2021 may mark the end of a 50 -year consensus about international students in Canada.

\section{Discussion}

While this article is primarily concerned with establishing a clear periodization of international student policy discussion, in so doing certain patterns become clear. There is substantial change described here, and it is clear that the end of the Cold War marked the beginning of something new in international student policy in Canada. But this history also shows that some of the contemporary features of international student policy that are often associated with globalization have their roots in an earlier era. For example, differential fees are a constant thread throughout this half-century. Similarly, while institutions showed considerable agency in the way they recruit and educate international students, it is also obvious that the state remains the primary policy agent here, as the catalyst for most significant shifts in international student policy has been the changing perspective of Canada's governments, both provincial and federal. This reflects Harney's (1988) point that issues of migration in Canada are always bound up with the national project, both practically and ideologically.

A third line that runs through this history is an emphasis on a very economistic notion of Canadian interests in this field. This has its origins in the work of the CBIE in the 1970s, but has reached its pinnacle in recent government strategy documents (e.g., Advisory Panel on Canada's International Education Strategy, 2012; British Columbia Ministry of Advanced Education, 2012; Government of Canada, 2014; Government of Canada \& Global Affairs Canada, 2019). Although institutions frequently argue for the educational value of international students, at the governmental level this is mostly ignored. Instead, international students are dehumanized in these materials, valued only to the extent that they can develop Canada's economy, whether during their studies or afterwards as immigrants. The pernicious effects of this attitude are widespread. They render any attempt at internationalism difficult, if not impossible, and contribute to the commodification of schooling for everyone. This extractive view also contributes to an attitude toward non-citizens that helps to justify the exploitation not only of international students, but also migrant workers (Walia, 2010).

\section{Conclusion}

Looking back at discussions of international students in the first 50 years of the CSSHE and CJHE, what might be most remarkable is the continuity rather than the changes. But there is reason to hope change may be on the way. The critical turn in scholarly literature opens the possibility of imagining a version of international education that could challenge the exploitative and exclusionary patterns that have defined it for a half-century. We will need these new ideas, as new global challenges such as COVID-19 and climate change are going to worsen existing colonial, capitalist inequalities across the globe. It is clear from this history that for those of us who want to develop a version of international education that is more just and equitable, it will require activism that can challenge not only the power of Canadian policy, but also the hegemony of ideas of the Canadian nation.

\section{Author Note}

All correspondence should be directed to dale.mccartney@ufv.ca. The author would like to thank Roopa Desai Trilokekar and Merli Tamtik for their assistance, and the anonymous reviewers of CJHE who helped to make this article stronger.

\section{References}

Advisory Panel on Canada's International Education Strategy. (2012). International education, a key driver of Canada's prosperity final report. Foreign Affairs and International Trade Canada. http://epe. lac-bac.gc.ca/100/201/301/weekly checklist/2012| internet/w12-45-U-E.html/collections/collection 2012/aecic-faitc/FR5-64-2012-eng.pdf 
Agosti, C. I., \& Bernat, E. (Eds.). (2018). University pathway programs: Local responses within a growing global trend. Springer. https://doi. org/10.1007/978-3-319-72505-5

Allison, J. (2007). Walking the line: Canadian federalism, the Council of Ministers of Education, and the case of international education, 1970-1984. Journal of Educational Administration and History, 39(2), 113-128. https://doi. org $/ 10.1080 / 00220620701342338$

Allison, J. (2016). A most Canadian odyssey: Education diplomacy and federalism, 1844-1984. Althouse Press.

Anderson, T. (2015). Seeking internationalization: The state of Canadian higher education. The Canadian Journal of Higher Education, 45(4), 166-187. https://doi.org/10.47678/cjhe.v45i4.184690

Association of Universities and Colleges of Canada. (2001). Recognizing the importance of international students in the Immigration and Refugee Protection Act. A brief submitted to the House of Commons Standing Committee on Citizenship and Immigration Canada regarding Bill C-11, the Immigration and Refugee Protection Act and its regulations. http://files.eric.ed.gov/fulltext/ED455736.pdf

Association of Universities and Colleges of Canada. (2014). Canada's universities in the world: AUCC internationalization survey. https://www.univcan. ca/wp-content/uploads/2015/07/internationalization-survey-2014.pdf

Bannerji, H. (1995). Thinking through: Essays on feminism, Marxism and anti-racism. Women's Press.

Bannerji, H. (2000). The dark side of the nation: Essays on multiculturalism, nationalism and gender. Canadian Scholars' Press.

Bartsiokas, T., Li, A., Hayes, S., \& Yaghdjian, G. (2017). Seneca 50: Yesterday, today and tomorrow. Seneca College.

Beck, K. (2008). Being international: Learning in a Canadian university [Doctoral dissertation, Simon Fraser University]. Simon Fraser University Summit Institutional Repository. https://sfu-primo.hosted. exlibrisgroup.com/permalink/f/15tu09f/01SFUL

\section{ALMA51298978150003611}

Beck, K. (2012). Globalization/s: Reproduction and resistance in the internationalization of higher education. Canadian Journal of Education/Revue Canadienne de l'éducation, 35(3), 133-148. https://journals.sfu.ca/cje/index.php/cje-rce/article/ view/1077

Bégin-Caouette, O. (2018). Le processus d'internationalisation des cégeps: Une analyse historique et géopolitique. Canadian Journal of Higher Education, 48(1), 99-117. https://doi.org/10.47678/cjhe. v48i1.188118

Birch, D. (1996a, January 25). Proposal for market-based tuition fees for international students. As quoted in the meeting of the University of British Columbia Board of Governors. https://bog.ubc.cal files/2015/07/MIN-BG-1996.01.pdf

Birch, D. (1996b, October 10). Report on International Student Initiative to UBC Board of Governors. As quoted in the meeting of the University of British Columbia Board of Governors. https://bog.ubc.cal files/2015/07/MIN-BG-1996.101.pdf

Boggs, A. M. (2009). Ontario's university tuition framework: A history and current policy issues. Canadian Journal of Higher Education, 39(1), 73-87. https:ll doi.org/10.47678/cihe.v39i1.495

Bottorff, J. L., Hamilton, C., Huisken, A., \& Taylor, D. (2020). Correlates of food insecurity among undergraduate students. Canadian Journal of Higher Education, 50(2), 15-23. https://doi.org/10.47678/ cjhe.v50i2.188699

Brewer, C. A. (2014). Historicizing in critical policy analysis: The production of cultural histories and microhistories. International Journal of Qualitative Studies in Education, 27(3), 273-288. https://doi.or g/10.1080/09518398.2012.759297

British Columbia Ministry of Advanced Education. (2012). British Columbia's international education strategy. Government of British Columbia. http:// www.aved.gov.bc.ca/internationaleducation/forms/ InternationalEducationStrategy WEB.PDF

Brunner, L. R. (2017). Higher educational institutions as emerging immigrant selection actors: A history 
of British Columbia's retention of international graduates, 2001-2016. Policy Reviews in Higher Education, 1(1), 22-41. https://doi.org/10.1080/233 22969.2016.1243016

Buckner, E., Clerk, S., Marroquin, A., \& Zhang, Y. (2020). Strategic benefits, symbolic commitments: How Canadian colleges and universities frame internationalization. Canadian Journal of Higher Education, 50(4), 20-36. https://doi.org/10.47678/ cjhe.vi0.188827

Calder, M. J., Richter, M. S., Mao, Y., Burns, K. K., Mogale, R. S., \& Danko, M. (2016). International students attending Canadian universities: Their experiences with housing, finances, and other issues. Canadian Journal of Higher Education, 46(2), 92-110. https://doi.org/10.47678/cjhe.v46i2.184585

Cameron, J. D. (2006). International student integration into the Canadian university: A post-World War Two historical case study. History of Intellectual Culture, 6(1), 1-18. https://journalhosting.ucalgary.ca/index. php/hic/article/view/68919

Campbell, N. (1980a, September 30). Davis issues 'racist' report. The Ubyssey. https://dx.doi. org/10.14288/1.0128260

Campbell, N. (1980b, October 2). Davis report 'inexcusably wrong.' The Ubyssey. https://dx.doi. org/10.14288/1.0127001

Canadian Bureau for International Education (Ed.). (1977). A question of self-interest: A statement on foreign students in Canada. Canadian Bureau for International Education.

Canadian Bureau for International Education. (2018). International students in Canada (CBIE Research in Brief). https://cbie.ca/wp-content/ uploads/2018/09/International-Students-in-Canada-ENG.pdf

Canadian Service for Overseas Students and Trainees. (1967). Communications: Newsletter of the Canadian Service for Overseas Students and Trainees. International House fonds (Box 11, Folder 11-55). UBC Archives, Vancouver, BC, Canada.

Canadian University Press. (1976, October 22). Black student union protests cutbacks. The Charlatan.

\section{https://archive.org/details/thecharleton06carl}

Canadian University Press. (1977, January 18). Two tier tuition legal but discriminatory. The Peak. https://newspapers.lib.sfu.ca/peak-1854/peak

Chakrabarty, D. (2000). Provincializing Europe: Postcolonial thought and historical difference. Princeton University Press.

Commission on Foreign Student Policy in Canada (Ed.). (1981). The right mix: The report of the Commission on Foreign Student Policy in Canada. Canadian Bureau for International Education.

Cudmore, G. (2005). Globalization, internationalization, and the recruitment of international students in higher education, and in the Ontario Colleges of Applied Arts and Technology. Canadian Journal of Higher Education, 35(1), 37-60. https://doi. org/10.47678/cjhe.v35i1.183491

Cui, D., Arthur, N., \& Domene, J. (2017). Accompanying partners of international students: Reflections on three issues. Canadian Journal of Higher Education, 47(1), 171-190. https://doi.org/10.47678/cjhe. v47i1.186193

Dennison, J. D. (2006). From community college to university: A personal commentary on the evolution of an institution. Canadian Journal of Higher Education, 36(2), 107-124. https://doi.org/10.47678/cjhe. v36i2.183541

Dennison, J. D., \& Schuetze, H. G. (2004). Extending access, choice, and the reign of the market: Higher education reforms in British Columbia, 1989-2004. Canadian Journal of Higher Education, 34(3), 13-38. https://doi.org/10.47678/cjhe.v34i3.183465

Desai-Trilokekar, R., \& Jones, G. (2015). Finally, an internationalization policy for Canada. International Higher Education, 71, 17-18. https://ejournals. bc.edu/index.php/ihe/article/view/6089

Duclos, V. (2011). L'intégration universitaire et sociale d'étudiants tunisiens et marocains inscrits dans une université francophone canadienne. Canadian Journal of Higher Education, 41(3), 101-101. https://doi.org/10.47678/cjhe.v41i3.2491

Editorial: CultureWorks raises questions. (2012, 
November 15). The Charlatan. https://charlatan. ca/2012/11/editorial-cultureworks-raises-questions/

Fairweather, R. G. L. (1976, December 13). "Scientific activities of government." Canada, Parliament, House of Commons, Hansard, 30th Parliament, 2nd Session. http://parl.canadiana.ca/view/oop. debates HOC3002 02/886? $r=0 \& s=3$

Falvo, N. (2010a, September 10). The pathway college concept. Academic Matters. https://academicmatters.ca/2010/09/the-pathway-college-concept/

Falvo, N. (2010b, October 14). Give Carleton funds to recruit foreign students. The Ottawa Citizen, A11. https://proxy.ufv.ca:2443/login?url=https:// www.proquest.com.proxy.ufv.ca:2443/newspapers/give-carleton-funds-recruit-foreign-students/ docview/758776179/se-2?accountid=10969

Fanelli, C., \& Meades, J. (2011). Austerity, Ontario and post-secondary education: The case of "Canada's Capital University." Journal for Critical Education Policy Studies, 9(2), 25. http://www.jceps.com/ wp-content/uploads/PDFs/09-2-13.pdf

Fees up for foreign students: Regrettable, racist. (1976, July). The Charlatan, 4. https://archive.org/details/ thecharleton06carl/page/12/mode/2up

Fisher, D., Rubenson, K., Shanahan, T., \& Trottier, C. R. (Eds.). (2014). The development of postsecondary education systems in Canada: A comparison between British Columbia, Ontario, and Quebec, 1980-2010. McGill-Queen's University Press.

Foreign Students in Canada. (1975, November). Speech given at BCSF conference in Kamloops, November 1975. Kay Riddell Rouillard fonds (B1993-0020 Box 3, Folder 2). University of Toronto Archives, Toronto, ON, Canada.

Frank, L. (2018). "Hungry for an education": Prevalence and outcomes of food insecurity among students at a primarily undergraduate university in rural Nova Scotia. Canadian Journal of Higher Education, 48(2), 109-129. https://doi.org/10.47678/cjhe. v48i2.188112

Freeman, I., \& Knight, P. (2007). Fostering global perspectives in undergraduate marketing students -A Kazakhstani/Canadian collaboration. Canadian
Journal of Higher Education, 37(2), 47-67. https:// doi.org/10.47678/cjhe.v37i2.540

Gale, T. (2001). Critical policy sociology: Historiography, archaeology and genealogy as methods of policy analysis. Journal of Education Policy, 16(5), 379-393. https://doi. org/10.1080/02680930110071002

Garson, K. (2016). Reframing internationalization. Canadian Journal of Higher Education, 46(2), 19. https://doi.org/10.47678/cjhe.v46i2.185272

Giamos, D., Lee, A. Y. S., Suleiman, A., Stuart, H., \& Chen, S.-P. (2017). Understanding campus culture and student coping strategies for mental health issues in five Canadian colleges and universities. Canadian Journal of Higher Education, 47(3), 136151. https://doi.org/10.47678/cjhe.v47i3.187957

Gottesman, I. (2016). The critical turn in education: From Marxist critique to poststructuralist feminism to critical theories of race. Routledge.

Government of Canada. (2014). Canada's international education strategy: Harnessing our knowledge advantage to drive innovation and prosperity. http:/l international.gc.ca/global-markets-marches-mondiaux/assets/pdfs/overview-apercu-eng.pdf

Government of Canada and Global Affairs Canada. (2019, August 22). Canada's international education strategy (2019-2024). https://www.international. gc.ca/education/strategy-2019-2024-strategie. aspx?lang=eng

Grayson, J. P. (2007). Unequal treatment and program satisfaction among students of European and Chinese origin. Canadian Journal of Higher Education, 37(3), 51-85. https://doi.org/10.47678/cjhe. v37i3.530

Green, A. R., Tulissi, A., Erais, S., Cairns, S. L., \& Bruckner, D. (2018). Building an inclusive campus: Developing students' intercultural competencies through an interreligious and intercultural diversity program. Canadian Journal of Higher Education, 48(3), 43-64. https://doi.org/10.47678/cjhe. v48i3.188134

Guo, S., \& Jamal, Z. (2007). Nurturing cultural diversity in higher education: A critical review of selected 
models. Canadian Journal of Higher Education, 37(3), 27-49. https://doi.org/10.47678/cihe.v37i3.529

Harder, D., \& Simon Fraser University Student Society Board of Directors. (2006, February 6). Official letters of concern in regards to IBT: From the Student Society. The Peak. https://newspapers.lib.sfu.cal peak-1246/peak

Harney, R. F. (1988). "So Great a Heritage as Ours": Immigration and the survival of the Canadian polity. Daedalus, 117(4), 51-97. https://www-jstor-org. proxy.ufv.ca:2443/stable/20025197

Hettich, W. P. (1977). Foreign student costs: A report on the costs of educating foreign students at Canadian universities. Canadian Bureau for International Education.

Holdaway, E. A., Bryan, W. M., \& Allan, W. H. (1988). International university students in Canada: Obtaining the information needed for policy making. $\mathrm{Ca}-$ nadian Journal of Higher Education, 18(3), 13-29. https://doi.org/10.47678/cjhe.v18i3.183043

Immigration Act, Revised Statutes of Canada (1976, C. 52). Retrieved from Acts of the Parliament of Canada (Annual Statutes) (via Heinonline): https:/l www-heinonline-org/HOL/Index?index=ss//sscan\&collection=ss|

International House at the University of British Columbia. (1983, June). Ontario foreign student fees reach giddying heights. Visa. University of British Columbia Faculty Association fonds (Box 17, Folder 17-14). University of British Columbia Archives, Vancouver, BC, Canada.

International Student Initiative. (2002, December 9). Presentation for International Education Branch Manitoba advanced education and training. Registrar's Office fonds (Box 98, Folder 09-10-11(2)). University of British Columba Archives, Vancouver, BC, Canada.

Israel, M., \& Lang, D. W. (1985, April 9). Visa students at the University of Toronto: The report of the Presidential Task Force on Foreign Students. Office of the Assistant Vice-President, Student Affairs fonds (A1993-0002, Box 06). University of Toronto Archives, Toronto, ON, Canada.
Johnstone, M., \& Lee, E. (2014). Branded: International education and 21st-century Canadian immigration, education policy, and the welfare state. International Social Work, 57(3), 209-221. https://doi. org/10.1177/0020872813508572

Johnstone, M., \& Lee, E. (2017). Canada and the global rush for international students: Reifying a neo-imperial order of western dominance in the knowledge economy era. Critical Sociology, 43(7-8), 10631078. https://doi.org/10.1177/0896920516654554

Jordan, R. (1982, January 22). Educate the rich? The Peak. https://newspapers.lib.sfu.ca/peak-141/peak

Kenyon, K. H., Frohard-Dourlent, H., \& Roth, W. D. (2012). The ambiguities of international student status: American undergraduate students in Canada. Canadian Journal of Higher Education, 42(1), 1-24. https://doi.org/10.47678/cjhe.v42i1.1991

Kerr, C. (1991). International learning and national purposes in higher education. American Behavioral Scientist, 35(1), 17-42. https://doi.org/10.1177\% 2F0002764291035001003

Knight, J. (1994). Internationalization: Elements and checkpoints. Canadian Bureau for International Education.

Knight, J. (1997). Internationalisation of higher education: A conceptual framework. In H. de Wit (Ed.), Internationalisation of higher education in Asia Pacific countries. European Association for International Education.

Knight, J. (2004). Internationalization remodeled: Definition, approaches, and rationales. Journal of Studies in International Education, 8(1), 5-31. https://doi.org/10.1177/1028315303260832

Knight, J. (2015). Updating the definition of internationalization. International Higher Education, 33. http://ejournals.bc.edu/ojs/index.php/ihe/article/ viewFile/7391/6588

Knight-Grofe, J., \& Deacon, L. (2016). Canada's global engagement challenge: A comparison of national strategies. International Journal: Canada's Journal of Global Policy Analysis, 71(1), 129-143. https:// doi.org/10.1177/0020702015622994 
Lambert, M. J. A. (1972, March 16). “Federal-Provincial fiscal arrangements act. Authorization of fiscal payments to and tax collection agreements with provinces." Canada, Parliament, House of Commons, Edited Hansard, 28th Parliament, 4th Session. https://www.lipad.ca/full/permalink/2790116/

Lang, K. E., \& Lang, D. W. (2002). "Flags and slots": Special interest groups and selective admissions. Canadian Journal of Higher Education, 32(2), 103142. https://doi.org/10.47678/cjhe.v32i2.183413

Larsen, M. A. (2015). Internationalization in Canadian higher education: A case study of the gap between official discourses and on-the-ground realities. $\mathrm{Ca}$ nadian Journal of Higher Education, 45(4), 101122. https://doi.org/10.47678/cjhe.v45i4.184907

Leong, W. (1983, November 4). Visa fees to rise. The Peak. https://newspapers.lib.sfu.ca/peak-204/peak

Levi, C. (2009). Canada: The Commonwealth Scholarship and Fellowship Plan. Van Hügel Institute for Critical Catholic Inquiry, St. Edmund's College. https://www.vhi.st-edmunds.cam.ac.uk/research/ past-research/Commonwealth/Canada

Levin, J. S. (2002). In education and in work: The globalized community college. Canadian Journal of Higher Education, 32(2), 47-77. https://doi. org/10.47678/cihe.v32i2.183411

Levin, J. S. (2003). Two British Columbia university colleges and the process of economic globalization. Canadian Journal of Higher Education, 33(1), 59-86. https://doi.org/10.47678/cjhe.v33i1.183428

Malette, N., \& Ismailzai, E. (2020). Building bridges to better bonds? Differential on-campus participation between international and domestic students. $\mathrm{Ca}-$ nadian Journal of Higher Education, 50(4), 72-86. https://doi.org/10.47678/cjhe.vi0.188817

Masri, A. E. (2020). International education policymaking: A case study of Ontario's Trillium Scholarship Program. Canadian Journal of Higher Education, 50(4), 1-19. https://doi.org/10.47678/cjhe. vi0.188819

Maynard, M. S., Meyer, S. B., Perlman, C. M., \& Kirkpatrick, S. I. (2018). Experiences of food insecurity among undergraduate students: "You can't starve yourself through school." Canadian Journal of Higher Education, 48(2), 130-148. https://doi. org/10.47678/cjhe.v48i2.188121

McBlane, R. (1981, June 29). Letter to the Honourable Lloyd Axworthy, Minister of Manpower \& Immigration. University of British Columbia International House fonds (Box 2, Folder 2-14-1). University of British Columbia Archives, Vancouver, BC, Canada.

McBlane, R. (1984). Director's Report to the University of British Columbia International House. University of British Columbia International House fonds (Box 2, Folder 2-3a). University of British Columbia Archives, Vancouver, BC, Canada.

McBlane, R. (1986, November). Submission to the president's task force on liaison, recruiting and admissions with particular reference to undergraduate international students. Registrar's Office Fonds (Box 105, Folder 20-07B). University of British Columbia Archives, Vancouver, BC, Canada.

McCartney, D. M. (2016). Inventing international students: Exploring discourses in international student policy talk, 1945-75. Historical Studies in Education/Revue d'histoire de l'éducation, 28(2), 1-27. https://historicalstudiesineducation.ca/index.php/ edu hse-rhe/article/view/4457/4727

McCartney, D. M. (2020). Border imperialism and exclusion in Canadian Parliamentary talk about international students. Canadian Journal of Higher Education, 50(4), 37-51. https://doi.org/10.47678/ cjhe.v50i4.188831

McCartney, D. M., \& Metcalfe, A. S. (2018). Corporatization of higher education through internationalization: The emergence of pathway colleges in Canada. Tertiary Education and Management, 24(3), 206-220. https://doi.org/10.1080/13583883.2 $\underline{018.1439997}$

Michael, S. O., \& Holdaway, E. A. (1992). Entrepreneurial activities in postsecondary education. Canadian Journal of Higher Education, 22(2), 15-40. https:/l doi.org/10.47678/cjhe.v22i2.183131

Montsion, J. M. (2018). Resource centre or experience desk? Producing spaces for delivering services to Indigenous and international students at uni- 
versities in Ontario, Canada. Canadian Journal of Higher Education, 48(1), 132-147. https://doi. org/10.47678/cjhe.v48i1.187971

Mueller, R. E. (2009). Does the Statue of Liberty still face out? The diversion of foreign students from the United States to Canada in the post 9/11 period. Canadian Journal of Higher Education, 39(1). http:/l ojs.library.ubc.ca/index.php/cjhe/article/view/492

Neice, D. C., \& Braun, P. H. (1977). A patron for the world? Canadian Bureau for International Education.

Parrott, H. C. (1976, May 4). Letter to Dr. F.C. Peters. Board of Governor Minutes fonds (RG 2.0.1, Bound volume). Wilfrid Laurier University Archives, Waterloo, ON, Canada.

Poitras, D. [@dpoitras01]. (2017, August 25). Unheard voices on the campus: the stories of the foreign students [Tweet]. Twitter. https://twitter.com/il events/901186122449117184

Poitras, D. (2019). Welcoming international and foreign students in Canada: Friendly relations with overseas students at the University of Toronto, 195168. Canadian Historical Review, 100(1), 22-45. https://doi.org/10.3138/chr.2017-0133

Prowse, J., \& Goddard, J. T. (2010). Teaching across cultures: Canada and Qatar. Canadian Journal of Higher Education, 40(1), 31-52. https://doi. org/10.47678/cjhe.v40i1.1568

Rae, P. (1996). New directions: Privatization and higher education in Alberta. Canadian Journal of Higher Education, 26(2), 59-79. https://doi.org/10.47678/ cjhe.v26i2.183238

Rahilly, T. J., \& Hudson, B. (2018). Canada's first international partnership for a pathway program. In C. I. Agosti \& E. Bernat (Eds.), University pathway programs: Local responses within a growing global trend (pp. 267-285). Springer International. https:/l doi.org/10.1007/978-3-319-72505-5

Roberts, S. C., \& Adam-Moodley, K. (1977). Institutional policies: Admissions, fees and quotas for foreign students at Canadian post-secondary institutions. Canadian Bureau for International Education.

Robertson, L. H., Holleran, K., \& Samuels, M. (2015).
Tailoring university counselling services to Aboriginal and international students: Lessons from Native and international student centres at a Canadian university. Canadian Journal of Higher Education, 45(1), 122-135. https://doi.org/10.47678/cjhe. v45i1.184262

Roslyn Kunin \& Associates. (2012). Economic impact of international education in Canada-An update. Final report. https://www.oph.fi/sites/default/files/ documents/economic-impact-of-int-edu-in-canada raportti.pdf

Sá, C. M., \& Sabzalieva, E. (2018). The politics of the great brain race: Public policy and international student recruitment in Australia, Canada, England and the USA. Higher Education, 75(2), 231-253. https://doi.org/10.1007/s10734-017-0133-1

Sabourin, L., \& Moore, R. J. (1977). Relevance or understanding? Canadian educational involvement with the third world. Canadian Bureau for International Education.

Samuel, E., \& Burney, S. (2003). Racism, eh? Interactions of South Asian students with mainstream faculty in a predominantly white Canadian university. Canadian Journal of Higher Education, 33(2), 81-114. https://doi.org/10.47678/cjhe.v33i2.183433

Sanguinetti, N. (1960). The story of FROS in Toronto. Kay Riddell Rouillard fonds (B1993-0020 Box 1, Folder 4). University of Toronto Archives, Toronto, ON, Canada.

Schuerholz-Lehr, S., Caws, C., Gyn, G. V., \& Preece, A. (2007). Internationalizing the higher education curriculum: An emerging model for transforming faculty perspectives. Canadian Journal of Higher Education, 37(1), 67-94. https://doi.org/10.47678/ cjhe.v37i1.183547

Senyshyn, S., \& Simon Fraser University Faculty Association Executive. (2006, February 6). Official letters of concern in regards to IBT: From the SFU Faculty Association. The Peak. https://newspapers. lib.sfu.ca/peak-1246/peak

Sharma, N. (2006). Home economics: Nationalism and the making of "migrant workers" in Canada. University of Toronto Press. 
Shaw, N. (1983, October 27$)$. Fees to rise by $25 \%$. The Peak. https://newspapers.lib.sfu.ca/peak-188/peak

Simon Fraser University Teaching Support Staff Union Executive. (2006, February 6). Official letters of concern in regards to IBT: From the SFU Teaching Support Staff Union. The Peak. https://newspapers. lib.sfu.ca/peak-1246/peak

Smith, B. (1998). The gender of history: Men, women, and historical practice. Harvard University Press.

Some University of Toronto Policies Concerning Student Visa Applicants. (1975). Report to Mr. Robin Ross, Vice-Provost, University of Toronto. Office of the Vice-Provost fonds (A1981-0025 Box 3, File $3 / 1 / 8)$. University of Toronto Archives, Toronto, ON, Canada.

Stearns, P. N. (1984). History and public policy. In G. J. McCall \& G. H. Weber (Eds.), Social science and public policy: The roles of academic disciplines in policy analysis (pp. 91-128). Associated Faculty Press.

Stein, S. (2017a). National exceptionalism in the 'EduCanada' brand: Unpacking the ethics of internationalization marketing in Canada. Discourse: Studies in the Cultural Politics of Education, 39(3), 1-17. https://doi.org/10.1080/01596306.2016.1276884

Stein, S. (2017b). Internationalization for an uncertain future: Tensions, paradoxes, and possibilities. The Review of Higher Education, 41(1), 3-32. https:/l doi.org/10.1353/rhe.2017.0031

Stein, S., Andreotti, V., \& Suša, R. (2019). Pluralizing frameworks for global ethics in the internationalization of higher education in Canada. Canadian Journal of Higher Education, 49(1), 22-46. https:/l doi.org/10.7202/1060822ar

Tamtik, M. (2017). Who governs the internationalization of higher education? A comparative analysis of macro-regional policies in Canada and the European Union. Comparative and International Education/Éducation Comparée et Internationale, 46(1), 2. https://doi.org/10.5206/cie-eci.v46i1.9307

Tamtik, M., Trilokekar, R. D., \& Jones, G. A. (2020). International education as public policy in Canada. McGill-Queen's University Press.
The Ad Hoc International Education Strategy Committee. (1993, October 12). A proposed strategy for internationalizing Wilfrid Laurier University. Laurier News, 2(6), 3-14.

Trilokekar, R. D. (2007). Federalism, foreign policy and the internationalization of higher education: $A$ case study of the international academic relations division, Department of Foreign Affairs and International Trade, Canada [Doctoral dissertation, Ontario Institute for Studies in Education of the University of Toronto]. ProQuest. https://www.proquest.com/ dissertations-theses/federalism-foreign-policy-internationalization/docview/304760120/se-2?accountid=14656

Trilokekar, R. D. (2010). International education as soft power? The contributions and challenges of Canadian foreign policy to the internationalization of higher education. Higher Education, 59(2), 131147. https://doi.org/10.1007/s10734-009-9240-y

Trilokekar, R. D., \& El Masri, A. (2016a). Canada's international education strategy: Implications of a new policy landscape for synergy between government policy and institutional strategy. Higher Education Policy, 29(4), 539-563. https://doi.org/10.1057/ s41307-016-0017-5

Trilokekar, R. D., \& El Masri, A. (2016b). The '[h]unt for new Canadians begins in the classroom': The construction and contradictions of Canadian policy discourse on international education. Globalisation, Societies and Education, 15(5). https://doi.org/10.1 $\underline{080 / 14767724.2016 .1222897}$

Trilokekar, R. D., \& Jones, G. A. (2020). Federalism and internationalization. In M. Tamtik, R. D. Trilokekar, \& G. A. Jones (Eds.), International education as public policy in Canada (pp. 29-49). McGill-Queen's University Press.

Trilokekar, R. D., \& Kizilbash, Z. (2013). IMAGINE: Canada as a leader in international education. How can Canada benefit from the Australian experience? Canadian Journal of Higher Education, 43(2), 1-26. https://doi.org/10.47678/cjhe.v43i2.2103

Tyack, D. B., \& Cuban, L. (1995). Tinkering toward utopia: A century of public school reform. Harvard University Press. 
Unions oppose Navitas. (2010, October 7). The Charlatan. https://charlatan.ca/2010/10/unions-oppose-navitas/

University of British Columbia International House Board of Directors. (1982, June 8). Minutes of meeting. University of British Columbia International House fonds (Box 2, Folder 2-3), University of British Columbia Archives, Vancouver, BC, Canada.

University of Toronto Students' Administrative Council. (1975, Oct.). The Students' Administrative Council's submission to the sub-committee of the Governing Council on Admissions and Awards with regard to student visa applicants to the University of Toronto. Kay Riddell Rouillard fonds (B1993-0020 Box 3, Folder 2). University of Toronto Archives, Toronto, ON, Canada.

Viczko, M., \& Tascón, C. I. (2016). Performing internationalization of higher education in Canadian national policy. Canadian Journal of Higher Education, 46(2), 1-18. https://doi.org/10.47678/cjhe. v46i2.186014

von Zur-Muehlen, M. (1977). The foreign student issues in 1976-77. Canadian Bureau for International Education.

Walia, H. (2010). Transient servitude: Migrant labour in Canada and the apartheid of citizenship. Race \& Class, 52(1), 71-84. https://doi. org/10.1177/0306396810371766

Walia, H. (2013). Undoing border imperialism. AK Press.

Walker, J. (2008). Social/corporate accountability: A university's "Trek" towards excellence. Canadian Journal of Higher Education, 38(2), 45-71. https:ll doi.org/10.47678/cjhe.v38i2.509

Welch, P., Groberman, R., \& Williams, T. (1984, February 29). Visa students in Canadian universities (draft policy). Prepared for Canadian Association of University Teachers Policy and Political Action Committee. University of British Columbia Faculty Association fonds (Box 17, Folder 17-14). University of British Columbia Archives, Vancouver, BC, Canada.

Wisenthal, M. (1999). Historical statistics of Canada, section W: Education (No. 1983001; Historical Statistics of Canada). Statistics Canada. https:/l www150.statcan.gc.ca/n1/en/pub/11-516-x/pdf/5220023-eng.pdf?st=Ylxn3oK1

Wollitzer, P. A. (1991). Introduction: Global change and the internationalization of higher education. American Behavioral Scientist, 35(1), 5-15. https://doi.or g/10.1177\%2F0002764291035001002

Zelmer, A. E., \& Johnson, N. A. (1988). International students in higher education: A follow-up study of university graduates. Canadian Journal of Higher Education, 18(3), 31-50. https://doi.org/10.47678/ cjhe.v18i3.183044

\section{Contact Information}

Dale M. McCartney

dale.mccartney@ufv.ca 